\title{
Research Note \\ PERFORMANCE OF MAHYCO GREEN LONG AND BHAKTAPUR LOCAL CUCUMBER CULTIVARS AT DIFFERENT SOWING DATES IN MID-HILL OF NEPAL
}

\author{
M. D. Sharma, Y. D. GC, K. M. Tripathi and S. P. Bhattarai \\ Institute of Agriculture and Animal Sciences, Rampur, Chitwan, Nepal
}

\begin{abstract}
An experiment was conducted in split plot design with three replications to determine the optimum date of sowing for commercial cultivation of cucumber at Lamjung Campus, Sundarbazar (750 m asl), Lamjung during December 1999 to November 2000. The cvs. Green Long and Bhaktapur Local were used in the main plot and the sowing dates in the sub-plot. Sowings were done on the 15th of the months December 1999 and February, April, June and August 2000 at an interval of two months. Manure and fertilizers were applied@20t farm yard manure and 120:60:50 NPK kg/ha in all the sowings. Yield attributing characters such as plant stand, vine growth, first male and first female flowers bearing nodes, number of female flowers per plot, sex ratio and number of harvests were insignificantly different in December and February sowings. However, the periods of phenophases such as sowing to the first male and first female flowers and sowing to first harvest and last harvest were significantly longer at December sowing followed by those at February sowing. The three latter sowings showed poor performance in respect to those characters. February sowing produced significantly the highest number of marketable fruits (79.16 thousand/ha) and marketable yield (53.97 t/ha) than the earlier December and three latter sowings. The December sowing also produced significantly higher marketable yield (23.76 t/ ha) than June and August sowings. Hence, the cvs. Green Long and Bhaktapur Local could not produce economic yields at April, June and August sowings at Sundarbazar (middle hill) Lamjung.
\end{abstract}

Key words: Cucumber cultivar, sowing date, marketable yield

\section{INTRODUCTION}

Cucumber (Cucumis sativus L.) is one of the important vegetable crops in Nepal. Cucumber has year round market, however, it is difficult to have year round production in the country. There are two major lean periods for the cucumber supply in Nepal. The first lean period extends from May to October and characterized by high temperature and long day photoperiodic condition favoring the excessive production of male flowers resulting in a few female flowers and low yield. The long day and higher temperatures generally promote production of male flowers (Seshadri, 1990). The normal temperature for the vegetative and reproductive growth in cucumber is $18-24^{\circ} \mathrm{C}$. Under the temperature condition over $32^{\circ} \mathrm{C}$, the reproductive performance is decreased by the production of more staminate flowers compared to pistillate. Similarly, over 14 hours of day length condition, the preponderance of the staminate flowers occur (Lower and Edwards, 1986). Such an inhibitory condition inhibiting female flower production occurs from May onward till September in the middle hills of Nepal. Hence, the cucumber production during this season is uneconomical due to the production of very few female flowers and fruits.

The second lean period is November-February, which is demonstrated by low temperature and short day photo period. The low temperature during this period is inhibitory for plant growth and imparts substantial chilling injury to cucumber.

In cucumber, the sex ratio, which determines the yield, is highly responsive to environmental conditions. In order to secure the year round production of cucumber and maintain productivity over the seasons, the sex ratio needs to be stabilized. Nonnecke (1989), Subedi et al. (1997) and Seshadri (1990) reported the genetic variations for the expression of femaleness. The authors have also indicated that the phenomenon depends on the growing environment in term of temperatures and day length. The same variety showed large variations in the expression of femaleness in different seasons. Hence, this experiment aimed to study the effect of sowing dates on sex expression and yield in two commercial cultivars of cucumber. 


\section{MATERIALS AND METHODS}

This study was conducted to determine the effect of sowing dates on the femaleness and yield of two cucumber cultivars Green Long and Bhaktapur Local during December 1999 to October 2000. Field experiment was carried out in split plot design with three replications. The cultivars were used in the main plot and the sowing dates in the sub-plot. The first, second, third, fourth and fifth sowings were done on the $15^{\text {th }}$ of the months December 1999 and February, April, June and August 2000 respectively at Sundarbazar, Lamjung. The size of individual sub-plot was $14.4 \mathrm{~m}^{2}$ that accommodated 10 plants. In the December sowing, seedlings were raised in the plastic pots under tunnel and transplanted at 3-4-leaf stage. Other sowings were directly in the field. The manure and fertilizers used were farmyard manure $20 \mathrm{t}$ and 120:60:50 $\mathrm{kg}$ NPK / ha. About one sixth of nitrogen and full dose of manure and other fertilizers were applied at the time of field preparation. Of the remaining, five split doses of nitrogen, the first one was applied at 25 days after sowing or transplanting and the rests at 10 days interval. Borax was also applied @ $20 \mathrm{~kg} / \mathrm{ha}$.

The plants were trained on bamboo stakes with laterals. Irrigation was applied at 3-15 days interval in winter-summer period and it was stopped in the main season of monsoon. Weeding was done at the time of side dressing. Six to seven sprays of Multiplex along with Rogor, Ridomil, Privental, Karathane or Dithane M45 were sprayed at 10 days interval. Fruits were harvested when they attained the weight of $250 \mathrm{~g}$. Several observations were made on growth characters, sex expression, yield attributing parameters and yield. Statistical analysis of the data was done using MSTAT-C computer program.

\section{RESULTS AND DISCUSSIONS}

\section{Plant stand and morphological characters}

The number of cucumber vines per plot at each sowing date was recorded at the time of last harvest. Initially, each plot accommodated 10 plants. The plant stand was at par at February and December sowings. It was statistically higher at February sowing than those at three latter sowings. The poor plant stand at latter sowings might be associated with the higher temperature and the heavy moisture conditions of soil and air, favorable for the spread of root and shoot diseases. Hence, the plant stand at earlier sowings was found better.

The morphological characters such as number of nodes and branches per plant and above groundmass per plant were recorded at the time of last harvest. The number of nodes per plant is also an important character, which indicates the growth of crop plants and their potential of bearing flowers and fruits. The December, February and April sowings had statistically no difference in number of nodes per plant. The June sowing had the highest number of nodes. The extensive growth of vine in June sowing might be associated with the warm and humid weather condition favorable for vegetative growth and influence yield. The node numbers at December and February sowings (44 and 48, respectively) were at par with better yield. Hence, the December and February sowings were found appropriate for proper growth of the vines. The June sowing was the best for intensive vine growth. The number of branches per plant indicates the growth performance of the vine. The effect of sowing dates on the branch number per plant was similar to that on node number per plant. The branch number per plant was statistically not different at three former sowings. August sowing was most adversely affected. The above groundmass per plant was recorded after the last harvest. The maximum amount of above ground mass $(1.66 \mathrm{~kg} /$ plant) was observed at February sowing but statistically it was at par to that at December sowing. It was significantly low at April, June and August sowings.

\section{Flowering behavior}

The sowing dates greatly influenced flowering characters such as the durations from sowing to the first male as well as first female flowers, the number of node bearing first male as well as first female flower, total number of female flowers per plot and the sex ratio i.e. male to female flowers (Table 1). The numbers of days to first male and first female flowers were significantly greater at December sowing followed by those at February and three latter sowings. The longer periods at early sowings were associated with slow growth rate of the crop due to low temperature during winter. At all sowings except December, the first male flower appeared earlier on the lower node of the vine than the first female flower. At June sowing, the significantly upper node $\left(26^{\text {th }}\right)$ had first female flower than those at other sowings. The period from sowing to the first female flower is an important 
indicator of earliness in cucumber. This period from sowing to first female flowering period was at par at February, June and August sowings, while at April sowing this period was the shortest (44 days). The node number bearing first female flower was not statistically different at three former sowings. At June sowing, significantly most upper node $\left(26^{\text {th }}\right)$ produced the first female flower while at August sowing the first female flower was produced on the $14^{\text {th }}$ node (Table 1 ).

The number of pistillate flowers per plot was significantly higher (168, 192 and 128 flowers/plot, respectively) at three former sowings than June sowing (40 flowers/plot). The sex ratio was statistically not different at December, February and August sowings. It was statistically higher at April and June sowings (40.58 and 38.08 flowers/plot respectively) than the rest. The lower sex ratios (male: female 5.93:1 and 10.02:1) recorded at December and February sowings, which were more favorable for the production of higher number of fruits. Similar results were also reported by Subedi et al. (1997)

Table 1. Effect of different dates of sowing on plant characters of two cucumber cultivars at Sundarbazar, Lamjung during winter-rainy season of $1999 / 2000$

\begin{tabular}{|lcccccccccc|}
\hline Sowing dates & $\begin{array}{c}\text { Plant } \\
\text { stand }\end{array}$ & $\begin{array}{c}\text { Days to } \\
\text { first male } \\
\text { flower }\end{array}$ & $\begin{array}{c}\text { First male } \\
\text { flowering } \\
\text { node }\end{array}$ & $\begin{array}{c}\text { Days to } \\
\text { first } \\
\text { pistillate } \\
\text { flower }\end{array}$ & $\begin{array}{c}\text { First } \\
\text { pistillate } \\
\text { flowering } \\
\text { node }\end{array}$ & $\begin{array}{c}\text { Number of } \\
\text { pistillate } \\
\text { flower/ } \\
\text { plot }\end{array}$ & $\begin{array}{c}\text { Sex ratio } \\
\text { male : } \\
\text { female }\end{array}$ & $\begin{array}{c}\text { Total } \\
\text { number of } \\
\text { nodes/ } \\
\text { plant }\end{array}$ & $\begin{array}{c}\text { Branches/ } \\
\text { plant }\end{array}$ & $\begin{array}{c}\text { Above } \\
\text { ground } \\
\text { mass } \\
\text { (kg/plant) }\end{array}$ \\
\hline Dec 15, 1999 & & & & & & & & & &
\end{tabular}

Mean in the column followed by same letters do not differ significantly by DMRT at 0.05 level

\section{Yield and yield components}

The harvest characters, such as days to first harvest, days to last harvest and fruit harvest number are shown in (Table 2). The period from sowing to the first harvest was the shortest (55 days) at April sowing and it was longer at earlier and latter sowings. Sowing dates had also significant effect on crop period from sowing to the last harvest. The crop period was significantly longer (158 days) at December sowing followed by those at February and latter sowings. This crop period was positively related with number of harvests. The harvest number was the highest (12.5 times) at February sowing, which was at par with that of December sowing and significantly greater than those of latter sowings. The number of harvests influenced the number of marketable fruits per ha. The number was the highest (79.16 thousand/ha) at February sowing followed by those at December and April sowings. At June and August sowings, the fruit number was very low. The February sowing produced the highest yield $(53.97 \mathrm{t} / \mathrm{ha})$ followed by December sowing $(23.76 \mathrm{t} / \mathrm{ha})$. The latter sowings produced very low yields and the tested cultivars Green Long and Bhaktapur Local are not suggested to grow at April, June and August sowings for commercial purpose. The results were similar to Lower and Edward (1986) and Seshadri (1990).

Table 2. Effect of different dates of sowing on fruit yield attributing characters at Sundarbazar, Lamjung during winter-rainy season of $1999 / 2000$

\begin{tabular}{|lccccccc|}
\hline Sowing dates & $\begin{array}{c}\text { Days to first } \\
\text { harvest }\end{array}$ & $\begin{array}{c}\text { Days to last } \\
\text { harvest }\end{array}$ & $\begin{array}{c}\text { Number of } \\
\text { harvest }\end{array}$ & $\begin{array}{c}\text { Marketable } \\
\text { fruits/ha (000) }\end{array}$ & $\begin{array}{c}\text { Unmarketable } \\
\text { fruits/plot }\end{array}$ & $\begin{array}{c}\text { Marketable } \\
\text { yield, t/ha }\end{array}$ & $\begin{array}{c}\text { Unmarketable } \\
\text { yield, kg/plot }\end{array}$ \\
\hline Dec 15, 1999 & $107.00 \mathrm{a}$ & $158.00 \mathrm{a}$ & $11.67 \mathrm{ab}$ & $38.18 \mathrm{~b}$ & $11.00 \mathrm{~b}$ & $23.76 \mathrm{~b}$ & $4.79 \mathrm{~b}$ \\
Feb 15, 2000 & $78.00 \mathrm{~b}$ & $130.00 \mathrm{~b}$ & $12.5 \mathrm{a}$ & $79.16 \mathrm{a}$ & $25.00 \mathrm{a}$ & $53.97 \mathrm{a}$ & $9.78 \mathrm{a}$ \\
Apr 15, 2000 & $55.00 \mathrm{~d}$ & $98.00 \mathrm{c}$ & $9.66 \mathrm{~b}$ & $22.91 \mathrm{bc}$ & $8.00 \mathrm{~b}$ & $13.8 \mathrm{c}$ & $3.70 \mathrm{~b}$ \\
Jun 15, 2000 & $71.00 \mathrm{bc}$ & $101.00 \mathrm{c}$ & $6.5 \mathrm{c}$ & $7.53 \mathrm{c}$ & $3.00 \mathrm{c}$ & $1.815 \mathrm{c}$ & $0.31 \mathrm{c}$ \\
\hline
\end{tabular}

Mean in the column followed by same letters do not differ significantly by DMRT at 0.05 level 


\section{ACKNOWLEDGEMENTS}

This study was the piece of the research project 'Light and temperature induced stress management for off-season cucumber production (HARP 105/99)' operated in 1999-2002 under the financial support of the Hill Agriculture Research Project funded by the British Government Department of International Development (DFID).

\section{REFERENCES CITED}

Lower, R. L. and M. D. Edwards. 1986. Cucumber breeding. In: M.J. Bassett (ed.) Breeding Vegetable Crops. AVI Publishing, Inc. pp. 173-204.

Nonnecke, I. L. 1989. Vegetable production. AVI Book, New York. 645 p.

Seshadri, U. S. 1990. Cucurbits. In: T.K. Bose and M.G. Som (eds.) Vegetable Crops in India. Naya Prokash, India. pp. 91-154.

Subedi, P. P., S. P. Bhattarai and J. P. Jaiswal. 1997. Increase female flower frequencies in cucumber (Cucumis sativus L.) cv. Bhaktapur Local. LARC Working Paper No. 97/28. Lumle Agricultural Research Centre, Kaski, Nepal. 